\section{Iron salts and vitamins: use, purchase and sources of obtainment among children in Brazil}

\author{
Sais de ferro e vitaminas: uso, aquisição e fontes \\ de obtenção para crianças brasileiras
}

Sales de hierro y vitaminas: uso, adquisición y
fuentes de obtención entre niños en Brasil
Juliana do Amaral Carneiro Diel 1

Andréa Dâmaso Bertoldi 2

Tatiane da Silva Dal Pizzol 1

Grupo PNAUM 3 doi: 10.1590/0102-311X00133317

\begin{abstract}
To verify the prevalence of use, purchase and sources of iron salts and vitamins by children aged from 0 to 12 years in Brazil. Population-based transversal study (Brazilian National Survey on Access, Utilization, and Promotion of Rational Use of Medicines - PNAUM), including 7,528 children up to 12 years of age. Information was obtained through questionnaires answered by the children's tutors, about the use of iron salts and vitamins 15 days before the interview; forms of financing, and sources of obtainment, sociodemographic characteristics, and presence of chronic disease. Descriptive and bivariate analyses were performed and the main variables were expressed by relative frequencies and 95\% confidence intervals (95\%CI). The prevalence of use of iron salts was 1.6\% (95\%CI: 1.2-2.1), with higher prevalence among children under 1 year old (8.5\%; 95\%CI: 6.3-11.5) and residents of the southeastern region (2.3\%; 95\%CI: 1.5-3.4). Prevalence of use of vitamins was 4.8\% (95\%CI: 4.2-5.6), with higher prevalence among children under 1 year old (24.3\%; 95\% CI: 20.3-28.7) and residents of the northern region (8.6\%; 95\% CI: 6.2-11.7). Purchase occurred by direct reimbursement for 41.6\% (95\%CI: 27.9-56.7) of the iron salts, and for 82.4\% (95\%CI: 76.3-87.2) of the vitamins. The iron salts were predominantly obtained from SUS pharmacies (51.5\%; 95\%CI: 36.4-66.4), and the vitamins from commercial pharmacies (80.6\%; 95\%CI: 77.4-85.6). The results suggested the use of iron salts in the Brazilian pediatric population was low, with reduction in use as age increased, regional differences and free-of-charge obtainment, predominantly from SUS.
\end{abstract}

Preschool Child; Iron Salts; Vitamins; Drug Utilization; Socieconomic

Factors

\author{
Correspondence \\ T. S. Dal Pizzol \\ Universidade Federal do Rio Grande do Sul. \\ Av. Ipiranga 2752, 2o andar, Porto Alegre, RS 90610-000, \\ Brasil. \\ tatiane.silva@ufrgs.br \\ 1 Universidade Federal do Rio Grande do Sul, Porto Alegre, \\ Brasil. \\ 2 Universidade Federal de Pelotas, Pelotas, Brasil. \\ 3 Other members listed at the end of the paper.
}




\section{Introduction}

Anemia and other micronutrient deficiencies in children are a global public health problem. Anemia affects about 300 million children worldwide 1. In 2011, the highest prevalence of anemia was found in children under 5 years of age (42.6\%; 95\%CI: 33.7-47.4) 1 . This condition can result in impairment of the following functions: growth and immunity; mental and psychomotor development, and school and cognitive performance. Diarrhea and respiratory infections, also resulting from anemia, contribute to increasing morbidity, in addition to overloading the health system 2 .

In Brazil, the estimated prevalence of anemia in children under 5 years of age is $20.9 \%$, according to the Brazilian National Survey of Demographic and Women and Child Health (PNDS, in Portuguese $2006{ }^{3}$. However, in a review performed by Vieira et al. ${ }^{4}$ with data from studies conducted in different epidemiological scenarios, higher prevalence values were found, ranging from $40.1 \%$ to $66.5 \%$ for population-based samples in populations in conditions of poverty.

World Health Organization (WHO) recommends the use of multiple micronutrient powders for children aged 6 months to 12 years in populations where anemia is a public health problem ${ }^{5}$. In Brazil, the Ministry of Health promotes supplementation programs to reduce the prevalence of anemia and nutritional deficiencies that affect the pediatric population. These programs include: NutriSUS 6 , which involves the fortification of infant feeding through the addition of these micronutrients in the powdered form directly in the food available in public schools and day care centers; the Brazilian National Iron Supplementation Program (PNSF, in Portuguese) 7, which provides children aged 6 months up to 24 months with ferrous sulfate, available at health facilities; and the Brazilian National Vitamin A Supplementation Program (PNSVA, in Portuguese) 8, which recommends the administration of megadoses of vitamin A to children aged from 6 months to 59 months, available at health units. According to systematic reviews conducted by The Cochrane Collaboration system, there is evidence in favor of iron salts 9 and vitamin A 10 supplementation.

The Brazilian National Health Survey (PNS, in Portuguese), conducted in 2013, estimated that $57.9 \%$ of the Brazilian children between the ages of 6 months and two years have received iron sulfate supplementation at some point in life 11. Studies dealing with this topic are scarce, especially those that have investigated aspects related to the access to these products. According to some studies, the use of vitamins by children between zero and 14 years varies from $4.6 \%$ to $12.6 \%$, and the use of iron sulfate from $0.8 \%$ to $31 \% 11,12,13,14,15,16$. The most recent population-based studies conducted in Brazil $13,14,16$ were geographically limited to a municipality or region of a state, and did not specifically evaluate iron salts and vitamins.

Studies based on data related to prevalence of use, characteristics of users, most used medicines and forms of access to this technology will make it possible to draw a pattern of use and identify problems associated with access and use, contributing to the evaluation of the impact of the Ministry of Health programs.

The aim of this study was to verify the prevalence of use, purchase and sources of iron salts and vitamins by children from zero to 12 years old in Brazil.

\section{Methods}

Individuals aged 12 years or under comprised the population study, resident in the urban zone of the five Brazilian regions that participated in the Brazilian National Survey on Access, Utilization, and Promotion of Rational Use of Medicines (PNAUM). PNAUM was a cross-sectional, population-based study with probability sampling, carried out between September 2013 and February 2014 in urban households at national level.

This sample could be considered similar to that of the Brazilian pediatric population when compared with the age and sex data of 2010 Population Census ${ }^{17}$. The PNAUM sampling plan provided for representativeness for the groups from 0 to 4 and 5 to 19 years without distinction of sex, as described in the methodological article of PNAUM 18. In this manuscript we did not use exactly the same age groups used in the sampling plan, so it was sex ( $50.9 \%$ boys and $49.1 \%$ girls), age ( $<2$ years: $13.9 \%$, 2-5 years: 29,0\%, 6-12 years: 57,1\%) and region of Brazil (North: 10.9\%, Northeast: 30.7\%, Southeast: 
37.9\%, South: 12.9\% and Central: 6.7\%) 19. Greater details about sample design, data collection logistics and quality control are described in the methodological article of PNAUM 18.

Specific questionnaires were used and answered by the main tutor of the child present in the residence at the time of the interview. At least three visits were made to each address in different shifts. Adults who were judged capable of reporting on the use of medicines and other supplements given to the children living in the household were identified as being the person responsible for them (those who responded on the children's behalf).

Information about the use of vitamins and iron salts was extracted from the question: "In the last 15 days, did (name of the child) use any vitamin, mineral supplement, appetite stimulant or tonic?". Whenever possible, the packaging or prescriptions of the medications used were presented to the interviewer. Data with reference to the purchase were obtained through the question: "was this medication paid for?"; "yes" answers were computed as payment, here considered direct reimbursement; "no" answers were computed as "free-of-charge medicines". The places where medications were obtained were extracted from the question "where did you obtain this medication?" and the answers were categorized into: retail pharmacy, Popular Pharmacy, Brazilian Unified National Health System (SUS) and others (charity institutions/church; free samples; friends, relatives and neighbors).

The medicines cited by the interviewees were identified in Anvisa (Brazilian Health Regulatory Agency) lists of medications, and classified by the drugs contained in their composition. The ironcontaining medications were classified into: isolated iron sulfate; associated iron sulfate; other forms of isolated iron, and other forms of associated iron. The medications containing vitamins were classified into: ascorbic acid, folic acid, calcitriol, calcium carbonate, polyvitamins and/or minerals, retinol, thiamine, vitamin B, vitamin D and vitamin A and D. The products classified as vitamin supplements were excluded because they were not registered as medications.

The outcomes investigated were: (1) prevalence of the use of iron salts; (2) prevalence of the use of vitamins; (3) forms of purchase of iron salts; (4) forms of purchase of vitamins; (5) sources of iron salts; and (6) sources of vitamins.

The variables analyzed were: sex (male/female), age (under 1 year, from 1 to 2 incomplete years; from 2 to 5 years and from 6 to 12 years); economic classification (A/B, C, D/E), in accordance with Brazilian Association of Research Companies (ABEP) 2013 20; region of Brazil (North, Northeast, Southeast, South, Central) and presence of chronic disease (yes/no).

According to Eisenstein 21, there is no consensus about which age range covers childhood, with the age limit ranging from 10 to 12 years. The Food and Drug Administration (FDA) in the Guidance for Industry - Clinical Investigation of Medicinal Products in the Pediatric Population 22 considers the same age group as that used in this study, which has also been found in previous studies 13,19,23,24,25.

The variable "presence of chronic disease" was used to verify if the use of these drugs could be different among healthier and less healthy children, assuming the presence of at least one chronic disease as an indicator of unhealthy behavior.

Descriptive and bivariate analyses were performed, and the main variables were expressed by relative frequencies and their respective $95 \%$ confidence intervals (95\%CI). The Pearson chi-square test was used to evaluate the statistical significance of the differences between groups, considering $5 \%$ level of significance. All the analyses were performed using the statistical package IBM SPSS 18.0 (IBM Corp., Armonk, USA), and the CSPLAN set of commands appropriate for analyzing complex samples and guaranteeing the required ponderation according to the sample design.

The project (PNAUM) was approved by Ethics Research Committee (CONEP, report n. 398.131, on September 16, 2013).The participants were interviewed only after their permission had been obtained with the signature of both participants and researcher of the free and informed consent term.

\section{Results}

The sample effectively collected and analyzed was composed of 41,433 individuals, of whom 7,528 were 12 years of age or younger. Of a total of 7,528 respondents, 26 did not know how to answer the main question ("In the last 15 days, did (name of the child) use any vitamin, mineral supplement, appetite stimulant or tonic?"). Table 1 presents the characteristics of the children who participated 
Table 1

Characteristics of children participating in PNAUM according to the use of iron salts and vitamins $(n=7,528)$ PNAUM, Brazil, 2014.

\begin{tabular}{|c|c|c|c|c|c|c|c|c|}
\hline Characteristic & $\%$ * & $95 \% \mathrm{Cl}$ & Iron salts (\%) & $95 \% \mathrm{Cl}$ & p-value ** & Vitamins (\%) & $95 \% \mathrm{Cl}$ & p-value ** \\
\hline \multicolumn{9}{|l|}{ Age in years } \\
\hline 0 to $<1$ & 6.7 & $6.2-7.3$ & 8.5 & $6.3-11.5$ & $<0.0001$ & 24.3 & $20.3-28.7$ & $<0.0001$ \\
\hline 1 to $<2$ & 6.8 & $6.2-7.5$ & 5.6 & $4.0-7.9$ & & 12.9 & $10.3-15.9$ & \\
\hline 2 to 5 & 26.9 & $25.2-28.6$ & 1.2 & $0.8-1.7$ & & 5.6 & $4.4-7.1$ & \\
\hline 6 to 12 & 59.6 & $57.3-61.8$ & 0.6 & $0.2-1.4$ & & 1.4 & $0.9-2.2$ & \\
\hline \multicolumn{9}{|l|}{ Sex } \\
\hline Male & 49.7 & $47.4-51.9$ & 1.5 & $1.1-2.0$ & 0.676 & 5.0 & $4.2-5.9$ & 0.684 \\
\hline Female & 50.3 & $48.1-52.6$ & 1.7 & $1.1-2.5$ & & 4.7 & $3.9-5.8$ & \\
\hline \multicolumn{9}{|c|}{ Economic class $* * *$} \\
\hline$A B$ & 16.8 & $14.6-19.2$ & 1.5 & $0.9-2.4$ & 0.448 & 5.4 & $4.0-7.1$ & 0.645 \\
\hline C & 56.2 & $53.4-58.9$ & 1.8 & $1.2-2.6$ & & 4.9 & $4.0-5.9$ & \\
\hline $\mathrm{DE}$ & 27.0 & $24.2-30.0$ & 1.3 & $0.8-2.0$ & & 4.5 & $3.6-5.6$ & \\
\hline \multicolumn{9}{|l|}{ Region } \\
\hline North & 9.9 & 7.4-13.3 & 1.4 & $0.9-2.4$ & 0.004 & 8.6 & $6.2-11.7$ & $<0.0001$ \\
\hline Northeast & 26.7 & $21.4-32.7$ & 1.2 & $0.8-1.9$ & & 7.0 & $5.6-8.7$ & \\
\hline Southeast & 41.2 & $34.2-48.5$ & 2.3 & $1.5-3.4$ & & 4.0 & $3.1-5.1$ & \\
\hline South & 13.8 & $10.4-18.1$ & 1.1 & $0.7-1.7$ & & 1.9 & $1.2-3.0$ & \\
\hline Central & 8.4 & $6.5-10.8$ & 0.6 & $0.4-1.0$ & & 2.7 & $1.9-3.8$ & \\
\hline \multicolumn{9}{|l|}{ Chronic disease } \\
\hline Yes & 9.9 & 8.6-11.3 & 2.5 & $1.2-5.4$ & 0.208 & 7.2 & $4.7-10.8$ & 0.063 \\
\hline No & 90.1 & $88.7-91.4$ & 1.5 & $1.2-1.9$ & & 4.6 & $3.9-5.3$ & \\
\hline Total & & & 1.6 & $1.2-2.1$ & & 4.8 & $4.2-5.6$ & \\
\hline
\end{tabular}

95\%Cl: 95\% confidence interval; PNAUM: Brazilian National Survey on Access, Utilization, and Promotion of Rational Use of Medicines.

* Percentages pondered by the sample weights;

** Pearson's chi-squared test;

*** In accordance with Brazilian Association of Research Companies (ABEP 2013).

in the PNAUM project and those who used iron salts and vitamins. Slightly over half (59.6\%) were children over the age of 6 years; $50.3 \%$ were girls; and $56.2 \%$ were from class $\mathrm{C}$. The larger portion of the children researched was concentrated (41.2\%) in the Southeastern region. Approximately $10 \%$ presented chronic disease.

The prevalence of the use of iron salts was 1.65\% (95\%CI: 1.2-2.1). Children under the age of 1 year showed the highest prevalence (8.5\%; 95\%CI: 6.3-11.5), and the children from 6 to 12 years, the lowest level (0.6\%; 95\%CI: 0.2-1.4) of use. The highest level of iron salt use occurred in the Southeastern region.

The prevalence of the use of vitamins was 4.8\% (95\%CI: 4.2-5.6). Children under the age of 1 year were those who made most use of this type of medication (24.3\%; 95\%CI: 20.3-28.7), and those living in the Northern region, the largest use (8.6\%; 95\%CI: 6.2-11.7).

Isolated iron sulfate represented over half of the iron salts used $(55.4 \%$ of all the medications containing iron salts). Of the vitamin medication used, $45.6 \%$ were polyvitamins and minerals, $31.5 \%$ ascorbic acid, and $16.7 \%$ vitamin $\mathrm{A}$ and $\mathrm{D}$ (Table 2).

The form of obtaining iron containing salts was 41.6\% (95\%CI: 27.9-56.7) through direct disbursement, and 58.3\% (95\%CI: 43.1-72.0) was free of charge. When the iron salts were purchased by direct reimbursement, the main source was the retail pharmacy (96.6\%; 95\%CI: 88.7-99.0) and when they were obtained free of charge the main source was SUS (89.3\%; 95\%CI: 74.5-96.0). When questioned about from where the iron salts were obtained, SUS was mentioned in just over half of the cases (51.5\%; 95\%CI: 36.4-66.4) (Figure 1). 
Table 2

Iron salts and vitamins used by children participating in PNAUM, Brazil, 2014.

\begin{tabular}{|c|c|c|}
\hline Medication & $\%$ & $95 \% \mathrm{Cl}$ \\
\hline \multicolumn{3}{|l|}{ Iron salts * $(n=178)$} \\
\hline Isolated ferrous sulfate & 55.4 & $43.5-66.7$ \\
\hline Other forms of isolated iron & 28.2 & $19.9-38.3$ \\
\hline Associated ferrous sulfate & 12.6 & $5.1-28.0$ \\
\hline Other forms of associated iron & 3.9 & $1.9-7.8$ \\
\hline Total & 100 & - \\
\hline \multicolumn{3}{|l|}{ Vitamins $(\mathrm{n}=718)$} \\
\hline Polyvitamins and minerals ** & 45.6 & $39.1-52.2$ \\
\hline Ascorbic acid & 31.5 & 26.4-37.1 \\
\hline Vitamins $A$ and D & 16.7 & $11.6-23.4$ \\
\hline Folic acid & 2.0 & $0.7-6.0$ \\
\hline Vitamin D & 1.9 & $0.8-4.5$ \\
\hline Calcitriol & 1.0 & $0.1-6.8$ \\
\hline Retinol & 0.5 & $0.2-1.2$ \\
\hline Calcium carbonate & 0.4 & $0.1-2.7$ \\
\hline Thiamine & 0.3 & $0.0-2.1$ \\
\hline Vitamin B & 0.1 & $0.1-0.4$ \\
\hline Total & 100 & - \\
\hline
\end{tabular}

95\%Cl: 95\% confidence interval; PNAUM: Brazilian National Survey on Access, Utilization, and Promotion of Rational Use of Medicines.

* Classification of medications containing iron: isolated ferrous sulfate, associated ferrous sulfate (for example: ferrous sulfate/phosphoric acid, ferrous sulfate/phosphoric acid/aromatic and therapeutic tonic plant extracts), other forms of isolated iron (for example: ferric polymaltose, iron amino acid chelates, iron glycinate), and other forms of associated iron (for example: chelated iron/folic acid/cyanocobalamin; ferric polymaltose/folic acid; iron amino acid chelates/folic acid; iron glycinate/folic acid);

** Classification of medications such as polyvitamins and minerals - examples: ascorbic acid/pyridoxine/ thiamine; buclizine/caffeine/lysine/nicotinamide/thiamine; cholecalciferol/ascorbic acid; ascorbic acid/pyridoxine/thiamine.

The form of obtaining vitamins was divided into purchase by direct reimbursement $(82.4 \%$; 95\%CI: 76.3-87.2); free of charge (17.1\%; 95\%CI: 12.3-23.2) and the source data missing was ignored (0.5\%; 95\%CI: 0.1-1.9). When the vitamins were purchased by direct reimbursement, the main source was the retail pharmacy (97.5\%; 95\%CI: 95.0-98.8) and when they were obtained free of charge the main source was SUS (88.9\%; 95\%CI: 75.5-95.4). When the interviewees were asked from where they obtained the vitamins, the predominant answer was commercial pharmacies (80.6\%; 95\%CI: 74.485.6) (Figure 1).

Table 3 presents the financing by direct reimbursement according to region and economic classification. Purchase of iron salts by direct reimbursement occurred most frequently in the Northern region, and purchase of vitamins, in the northeastern region. The purchase of both iron salts and vitamins occurred more frequently in the economic classes A/B. Despite presenting differences between regions and economic classes in relation to the point estimates of prevalence, we observed that only the use of vitamins in comparison with the regions was statistically significant.

\section{Discussion}

The results of this study showed that the use of iron salts by the Brazilian pediatric population was low, and lower than the consumption of vitamins. The use of iron salts was lower in older children. The highest level of iron salt use occurred in the Southeastern region, and of vitamins, in the Northern 


\section{Figure 1}

Forms of purchase and sources of iron salts and vitamins PNAUM, Brazil, 2014.

1a) Forms of purchase of iron salts

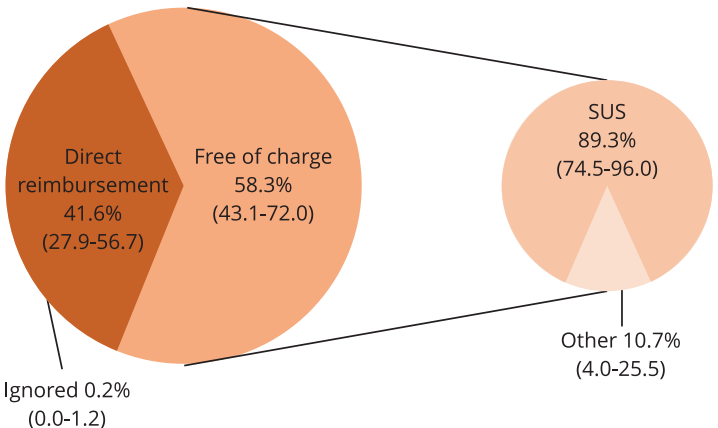

1c) Forms of obtaining iron salts

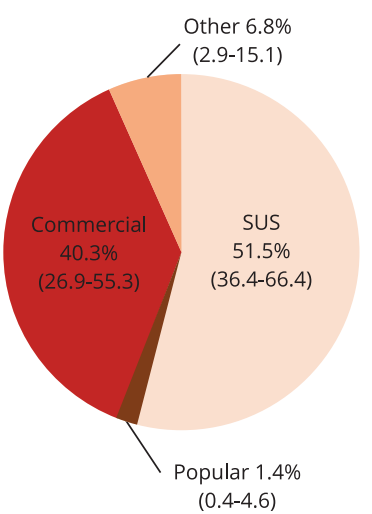

1b) Forms of purchase of vitamins

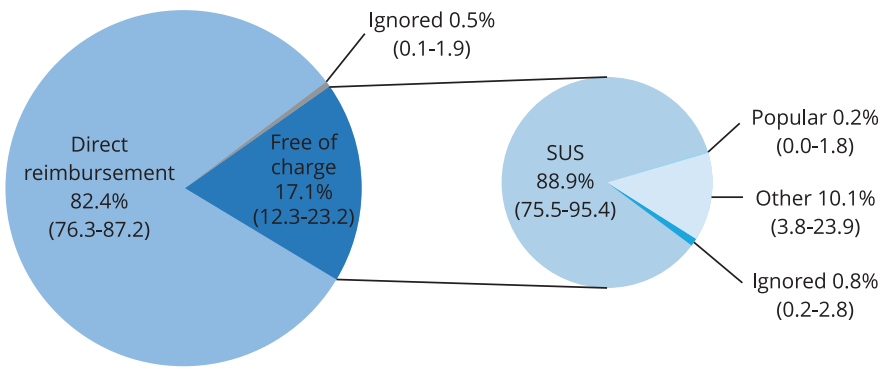

1d) Forms of obtaining vitamins

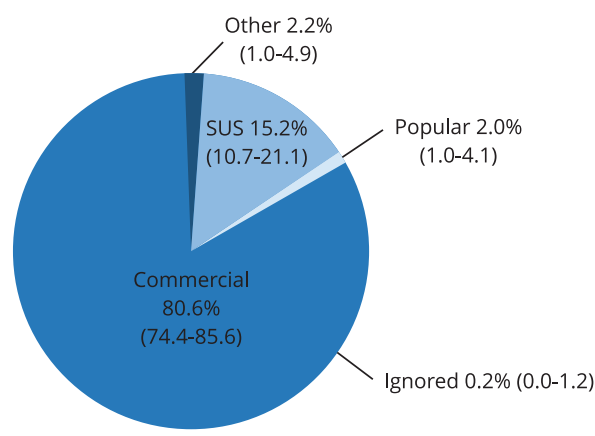

Other: charity institution/church, free samples, friends, relatives or neighbors; PNAUM: Brazilian National Survey on Access, Utilization, and Promotion of Rational Use of Medicine.

region. Most iron salts were obtained free of charge, whereas the larger portions of vitamins were purchased by direct reimbursement.

The prevalence of $1.6 \%$ of the use of iron salts was similar to the one found in previous studies, such as those by Béria et al. 12 (1.7\%), with children up to 4 years of age in Pelotas, Rio Grande do Sul State, Brazil; and by Santos et al. 15 (2\%), with children from 4 to 11 years old in Salvador, Bahia State Brazil. Nevertheless, other population-based studies conducted in Brazil pointed out higher prevalence values: $11.5 \%$ 13, with children under 14 years in the Jequitinhonha Valley, Minas Gerais State, Brazil; $11.1 \% 16$ with children aged 1 to 5 years in Vitória, Espírito Santo State, Brazil; $31.5 \%$ in PNDS 2006 26; and 57.9\% in PNS 2013 11. Comparison with the results of these studies must consider that the studies with higher prevalence values used considerably longer periods of records (the last 6 months in PNDS 26 and at some point in life in PNS 11) than other studies using the same period of time as PNAUM (15 days prior to the interview) 13,15. Other methodological aspects, such as the format of the question the interviewee was asked (medication-directed or not), in addition to the children's characteristics, such as age and health conditions, may explain the differences in the prevalence values found in the studies 11,13,16,26. In spite of the importance of using iron salts to prevent anemia 9 , 
Table 3

Financing by direct reimbursement of iron salts and vitamins, by geographic region and economic classification according to PNAUM, Brazil, 2014.

\begin{tabular}{|c|c|c|c|c|}
\hline & \multicolumn{2}{|c|}{ Iron salts } & \multicolumn{2}{|c|}{ Vitamins } \\
\hline & $\%$ & $95 \% \mathrm{Cl}$ & $\%$ & $95 \% \mathrm{Cl}$ \\
\hline Region & \multicolumn{2}{|c|}{$p=0.299$} & \multicolumn{2}{|c|}{$p=0.007$} \\
\hline North & 73.7 & $40.5-92.0$ & 85.0 & $72.9-92.3$ \\
\hline Northeast & 50.9 & $35.2-66.4$ & 93.8 & $84.2-97.7$ \\
\hline Southeast & 32.8 & $15.0-57.4$ & 68.5 & $54.2-79.9$ \\
\hline South & 42.3 & 20.9-67.0 & 77.4 & $53.7-91.0$ \\
\hline Central & 46.9 & $22.5-72.9$ & 88.4 & 76.7-94.7 \\
\hline ABEP & \multicolumn{2}{|c|}{$p=0.684$} & \multicolumn{2}{|c|}{$p=0.720$} \\
\hline $\mathrm{A} / \mathrm{B}$ & 56.7 & $29.5-80.4$ & 86.6 & $69.0-94.9$ \\
\hline C & 39.4 & $21.4-60.8$ & 82.7 & $75.0-88.4$ \\
\hline $\mathrm{D} / \mathrm{E}$ & 38.1 & 20.9-58.8 & 78.4 & $64.3-88.0$ \\
\hline Total & 41.6 & 27.9-56.7 & 82.4 & $76.3-87.2$ \\
\hline
\end{tabular}

95\%Cl: 95\% confidence interval; ABEP: Brazilian Association of Research Companies; PNAUM: Brazilian National Survey on Access, Utilization, and Promotion of Rational Use of Medicines.

the consumption may be considered low in all the age ranges analyzed in the PNAUM survey. Even among younger children ( $<2$ years) the consumption of iron salts was low, due to the recommendation by PNSF of prophylactic use in all children between the ages of six months and two years.

If we compare the prevalence of the use of iron salts in this study with data from health inquiries conducted in Europe, such as those by Du et al. 23, conducted in Germany; and Carrasco et al. 24, in Spain, we would verify similar prevalence values (1.1\% and 3.4\%, respectively). However, the prevalence values of anemia in these countries were lower than those in Brazil, according to WHO data 1. In the USA, where the prevalence of iron deficiency affected 8 to $14 \%$ of the children, according to the Slone Study, the use of iron salts among children from 0 to 11 years in the 7 days prior to the interview was $9.7 \%$, a situation that may be related to the high consumption of vitamin and mineral supplements by American children 25. The fact that those responsible for the children did not recognize iron sulfate as a form of preventing anemia, in addition to the lack of knowledge about the consequences of anemia and difficulties with adhesion, resulting from the adverse effects, may be factors that complicated the use of this medication $16,27,28$.

The prevalence of the use of vitamins (4.8\%) was close to the values found in other studies, ranging from $4.6 \%$ to $11.5 \% 12,13,15,16,23$. The higher prevalence in the use of vitamins in comparison with iron salts may be associated with the sale condition of some vitamins, which do not require prescriptions and are considered safe by the population 29 ; or because people do not consider vitamins to be medicines and use them to complement a poor diet.

The prevalence values of iron salts and vitamins found were lower in older children. This datum is in agreement with the prevalence of anemia that was shown to be higher in children under the age of 5 years 30 and with the recommendation by PNSF of prophylactic use up to 2 years of age. Particularly between the ages of six months and two years, the need for this mineral increases due to the children's rapid growth 31 . Other studies also observed a low prevalence of anemia in older children $26,32,33$. The use of iron salts presented a higher prevalence in children from the Southeastern region, and lower prevalence in the population from the Central region, in agreement with the prevalence of anemia in these regions, pointed out by PNDS 2006 (higher prevalence in the Northeastern [25.5\%], Southeastern [22.6\%] and Southern [21.5\%] regions; and lower prevalence in the Northern [10.4\%] and Central [11\%] regions) 26. PNS 2013 also found higher consumption of iron sulfate by children of 6 months up to 2 years of age 11 in the Southeastern region, in comparison with the other regions. The differences 
in the prevalence of use of iron salts among regions could also be associated with other factors, such as differences in coverage of health services and in the operationalization of PNSF.

The use of vitamins was greater in the Northern and Northeastern regions and lower in the Southern region. These differences may be explained, at least partially, by the potential use of vitamins in self-medication; and data of PNAUM itself pointed out reasons for the higher prevalence of self-medication in these two regions 34. Furthermore, data from PNDS have shown that the Northern region has the highest rates of weight-age and weight-height deficit for children under the age of 5 years in comparison with the other regions. This may be linked to the high level of use of vitamins by children from the Southern region ${ }^{3}$.

Iron sulfate was the iron salt used in little over half of the cases. Iron sulfate is provided free of charge by SUS through PNSF, and, until the end of 2015, it could be acquired by co-payment in the Brazilian Popular Pharmacy services of the network itself, favoring a higher level of its use in comparison with more expensive isolated irons (iron amino acid chelates and ferric polymaltose), according to the Anvisa 35 bulletin. The systematic review conducted by De-Regil et al. 9 found that iron sulfate does not present hematological outcome results different from those presented by the other forms of iron. Moreover, ferrous salts present high frequency of up to $40 \%$ adverse effects including: pyrosis, epigastralgia, nausea, vomiting, metallic taste, darkening of the teeth, dyspepsia, abdominal discomfort, diarrhea, and constipation. The symptoms are dose-related and tend to disappear in 2 to 3 days after the onset of treatment. Due to the frequency and intensity of adverse effects of iron salts, they have lower tolerance, worse adhesion to therapy, and thus worse results in comparison with ferric polymaltose 36,37 .

Among the vitamins, the polyvitamins, ascorbic acid and vitamin A+D were those most used, in agreement with previous studies 12,13. Data from PNAUM published in 2016 revealed that ascorbic acid was ranked the fifth most used medication among children ${ }^{19}$. Ascorbic acid is possibly being used to improve the absorption of iron, or to prevent influenza and colds, although this latter use is not backed by evidence 38 .

Direct reimbursement for purchasing of iron salts occurred with higher frequency than was expected, considering that iron sulfate is present in the Brazilian National List of Essential Medicines (RENAME, in Portuguese) and in PNSF. The presence of iron sulfate is consistent with systematic reviews that demonstrate similar efficacy ${ }^{9}$ and tolerability 39 to other forms of iron. On the one hand, the option not to use the services offered by SUS, and on the other hand, lack, irregularity and/or unavailability of medication supplies in the public health services, may lead to a significant portion of the population buying the medications with their own resources.

Differently from the iron salts, vitamins were predominantly purchased by direct reimbursement (88.9\%) from the retail pharmacy. These findings are in agreement with data from the Brazilian Household Budget Surveys (PNAD, in Portuguese) 2008-2009, which demonstrated that vitamins represented the fifth group of medications on which Brazilian families spent their budget 40 . A factor that contributed to the lower access to vitamins obtained free of charge is the reduced number of this class of drugs available in the list of the basic component of pharmaceutical care. On the other hand, many of the vitamins used by children consist of polyvitamins and minerals, some in combinations and amounts that are not justified by evidence, and whose use and availability are not stated in RENAME.

In this study, we did not collect data about diagnosis of anemia and other micronutrient deficiencies in the children, which prevented these conditions from being related to the therapeutic use of iron salts and vitamins. Despite the size and characteristics of the sample (7,528 children aged 0 to 12 residing in municipalities of different sizes from the 5 regions of the country, including all capitals), we cannot affirm that the sample was representative of the entire Brazilian pediatric population due to the following factors: differences in the coverage network, income level and education of parents/ tutors, cultural differences and access to medicines, age differences used for this study (0 to 12 years) in relation to the sampling plan for representativeness ( 0 to 4 years and 5 to 19 years) used in the PNAUM, among other factors. Finally, specific questions about feeding received at day care centers and schools, and about administration of megadoses of vitamin A to children at health services were not included in the questionnaire, to enable the PNSVA and NutriSUS to be assessed to some extent. However, measures of iron salts were adequate to assess the scope of the PNSF in the five regions of the country. 
In conclusion, the use of iron salts by the Brazilian pediatric population was low, and lower than the consumption of vitamins, which suggested that the PNSF still needs to attain part of the population that would be within the recommended criteria for use. The use of iron salts and vitamins was lower in older children, in accordance with this stage of development in which the need for iron salts and vitamins is reduced. The higher level of use of iron salts occurred in the Southeastern region. Most iron salts were obtained free of charge, because they were made available by SUS and their use was recommended by PNSF, which should have contributed to a higher consumption than the value found. The majority of vitamins, in turn, were purchased by direct reimbursement. These data should be combined with future qualitative methodologies that involve other aspects of access policies and perception on use of iron salts and vitamins by parents/tutors.

\section{Contributors}

J.A. C. Diel contributted in the protocol for analysis, data preparation, data analysis, writing and approval of the final version of the manuscript. A. D. Bertoldi contributted in the protocol for the analysis, interpretation of results, critical review of intellectual content and approval of the final version of the manuscript. T. S. Dal Pizzol contributted in the protocol for analysis, interpretation of results, critical revision of intellectual content, writing and approval of the final version of the manuscript.

\section{Other members of the PNAUM Group}

Luiz Roberto Ramos; Mareni Rocha Farias; Maria Auxiliadora Oliveira; Noemia Urruth Leo Tavares; Paulo Sergio Dourado Arrais; Sotero Serrate Mengue; Vera Lucia Luiza.

\section{Acknowledgments}

The authors thanks Secretariat of Science, Technology and Strategic Inputs oh the Brazilian Ministry of Health (SCTIE/MS) $(25000.111834 / 2)$ for the financial support.

\section{References}

1. World Health Organization. The global prevalence of anaemia in 2011. Genebra: World Health Organization; 2015.

2. Wang B, Zhan S, Gong T, Lee L. Iron therapy for improving psychomotor development and cognitive function in children under the age of three with iron deficiency anaemia. Cochrane Database Syst Rev 2013; (6):CD001444.

3. Ministério da Saúde. Pesquisa Nacional de Demografia e Saúde da Criança e da Mulher PNDS 2006: dimensões do processo reprodutivo e da saúde da criança. Brasília: Ministério da Saúde; 2009. (Série G. Estatística e Informação em Saúde).

4. Vieira RCS, Ferreira HS. Prevalência de anemia em crianças brasileiras, segundo diferentes cenários epidemiológicos. Rev Nutr (Online) 2010; 23:433-44.

5. World Health Organization. WHO guideline: use of multiple micronutrient powders for point-of-use fortification of foods consumed by infants and young children aged 60-23 months and children aged 2-12 years. Genebra: World Health Organization; 2017. 
6. Ministério da Saúde; Ministério da Educação. NutriSUS: caderno de orientações: estratégia de fortificação da alimentação infantil com micronutrientes (vitaminas e minerais) em pó. Brasília: Editora do Ministério da Saúde; 2015.

7. Departamento de Atenção Básica, Secretaria de Atenção à Saúde, Ministério da Saúde. Programa Nacional de Suplementação de Ferro: manual de condutas gerais. Brasília: Ministério da Saúde; 2013.

8. Departamento de Atenção Básica, Secretaria de Atenção à Saúde, Ministério da Saúde. Manual de condutas gerais do Programa Nacional de Suplementação de Vitamina A. Brasília: Ministério da Saúde; 2013.

9. De-Regil LM, Jefferds MED, Sylvetsky AC, Dowswell T. Intermittent iron supplementation for improving nutrition and development in children under 12 years of age. Cochrane Database Syst Rev 2011; (12):CD009085.

10. Imdad A, Mayo-Wilson E, Herzer K, Bhutta ZA. Vitamin A supplementation for preventing morbidity and mortality in children from six months to five years of age. Cochrane Database Syst Rev 2017; 3:CD008524.

11. Instituto Brasileiro de Geografia e Estatística, organizador. Pesquisa nacional de saúde, 2013: ciclos de vida: Brasil e grandes regiões. Rio de Janeiro: Instituto Brasileiro de Geografia e Estatística; 2015.

12. Béria JU, Victora CG, Barros FC, Teixeira AB, Lombardi C. Epidemiologia do consumo de medicamentos em crianças de centro urbano da região sul do Brasil. Rev Saúde Pública 1993; 27:95-104.

13. Cruz MJB, Dourado LFN, Bodevan EC, Andrade RA, Santos DF. Medication use among children 0-14 years old: population baseline study. J Pediatr (Rio J) 2014; 90:608-15.

14. Moraes CG, Mengue SS, Tavares NUL, Dal Pizzol T da S. Utilização de medicamentos entre crianças de zero a seis anos: um estudo de base populacional no sul do Brasil. Ciênc Saúde Coletiva 2013; 18:3583-93.

15. Santos DB, Barreto ML, Coelho HLL. Utilização de medicamentos e fatores associados entre crianças residentes em áreas pobres. Rev Saúde Pública 2009; 43:768-78.
16. Saraiva BCA, Soares MCC, Santos LC, Pereira SCL, Horta PM. Iron deficiency and anemia are associated with low retinol levels in children aged 1 to 5 years. J Pediatr (Rio J) 2014; 90:59399.

17. Instituto Brasileiro de Geografia e Estatística. Censo demográfico 2010. Características da população e dos domicílios: resultado do universo. Rio de Janeiro: Instituto Brasileiro de Geografia e Estatística; 2011.

18. Mengue SS, Bertoldi AD, Boing AC, Tavares NUL, Pizzol TSD, Oliveira MA, et al. Pesquisa Nacional sobre Acesso, Utilização e Promoção do Uso Racional de Medicamentos (PNAUM): métodos do inquérito domiciliar. Rev Saúde Pública 2016; 50 Suppl 2:4s.

19. Pizzol TSD, Tavares NUL, Bertoldi AD, Farias MR, Arrais PSD, Ramos LR, et al. Uso de medicamentos e outros produtos com finalidade terapêutica entre crianças no Brasil. Rev Saúde Pública 2016; 50 Suppl 2:12s.

20. Associação Brasileira de Empresas de Pesquisa. Critério de classificação econômica ABEP - 2013. http://www.abep.org/criterio-brasil (accessed on 09/Jun/2017).

21. Eisenstein E. Adolescência: definições, conceitos e critérios. Adolescência \& Saúde 2005; 2:67.

22. U.S. Department of Health and Human Services; Food and Drug Administration; Center for Drug Evaluation and Research; Center for Biologics Evaluation and ResearchFood and Drug Administration. Guidance for industry: E11 clinical investigation of medicinal products in the pediatric population. Rockville: Food and Drug Administration; 2000.

23. Du Y, Knopf H. Self-medication among children and adolescents in Germany: results of the National Health Survey for Children and Adolescents (KiGGS). Br J Clin Pharmacol 2009; 68:599-608.

24. Carrasco-Garrido P, Jiménez-García R, Barrera VH, Andrés AL, Miguel ÁG. Medication consumption in the Spanish paediatric population: related factors and time trend, 1993-2003. Br J Clin Pharmacol 2009; 68:455-61. 
25. Vernacchio L, Kelly JP, Kaufman DW, Mitchell AA. Vitamin, fluoride, and iron use among US children younger than 12 years of age: results from the slone survey 1998-2007. J Am Diet Assoc 2011; 111:285-9.

26. Ministério da Saúde. PNDS 2006 - Pesquisa Nacional de Demografia e Saúde da Criança e da Mulher: relatório. Brasília: Ministério da Saúde; 2008

27. Azeredo CM, Cotta RMM, Silva LS, Franceschini SCC, Sant'Ana LFR, Lamounier JA. A problemática da adesão na prevenção da anemia ferropriva e suplementação com sais de ferro no município de Viçosa (MG). Ciênc Saúde Coletiva $2013 ; 18: 827-36$

28. Sezik HA, Can H, Kurnaz MA, Tuna M, Ay Z. Use of iron supplements in children aged 1-2 years with iron deficiency anemia: a cross-sectional study. Pak J Med Sci 2015; 31:1227-32.

29. Almeida MR, Castro LL, Caldas ED. Conhecimentos, práticas e percepção de risco do uso de medicamentos no Distrito Federal. Rev Ciênc Farm Básica Apl 2011; 32:225-32.

30. Jordão RE, Bernardi JLD, Barros Filho AA. Prevalência de anemia ferropriva no Brasil: uma revisão sistemática. Rev Paul Pediatr 2009; 27:90-8.

31. Departamento de Atenção Básica, Secretaria de Atenção à Saúde, Ministério da Saúde. Cadernos de Atenção Básica: carências de micronutrientes. Brasília: Ministério da Saúde; 2007. (Série A. Normas e Manuais Técnicos).

32. Oliveira EA, Bertoldi AD, Domingues MR, Santos IS, Barros AJ. Uso de medicamentos do nascimento aos dois anos: coorte de nascimentos de Pelotas, RS, 2004. Rev Saúde Pública 2010; 44:591-600.
33. Osório MM, Lira PI, Batista-Filho M, Ashworth A. Prevalence of anemia in children 6-59 months old in the state of Pernambuco, Brazil. Rev Panam Salud Publica 2001; 10:101-7.

34. Arrais PSD, Barreto ML, Coelho HLL. Drug prescription and dispensing from the patient's perspective. Cad Saúde Pública 2007; 23:92737.

35. Agência Nacional de Vigilância Sanitária. Anemia por deficiência de ferro. Saúde \& Economia 2013; IV(9).

36. Cançado RD, Lobo C, Friedrich JR. Tratamento da anemia ferropriva com ferro por via oral. Rev Bras Hematol Hemoter 2010; 32 Suppl 2:114-20.

37. Toblli JE, Brignoli R. Iron (III)-hydroxide polymaltose complex in iron deficiency anemia. Arzneimittelforschung 2007; 57:431-8.

38. Douglas RM, Hemilä H, Chalker E. Vitamin $\mathrm{C}$ for preventing and treating the common cold. Cochrane Database Syst Rev 2007; (3):CD000980

39. Cancelo-Hidalgo MJ, Castelo-Branco C, Palacios S, Haya-Palazuelos J, Ciria-Recasens M, Manasanch J, et al. Tolerability of different oral iron supplements: a systematic review. Curr Med Res Opin 2013; 29:291-303.

40. Garcia LP, Sant'Anna AC, Magalhães LCG, Freitas LRS, Aurea AP. Gastos das famílias brasileiras com medicamentos segundo a renda familiar: análise da Pesquisa de Orçamentos Familiares de 2002-2003 e de 2008-2009. Cad Saúde Pública 2013; 29:1605-16. 


\section{Resumo}

O estudo teve como objetivo verificar a prevalência do uso, aquisição e fontes de saís de ferro e vitaminas para crianças entre 0 e 12 anos de idade no Brasil. Foi realizado um estudo transversal de base populacional (Pesquisa Nacional sobre Acesso, Utilização e Promoção do Uso Racional de Medicamentos - PNAUM), incluindo 7.528 crianças até 12 anos de idade. As informações foram obtidas através de questionários respondidos pelos pais ou responsáveis, sobre o uso de sais de ferro e vitaminas nos 15 dias anteriores à entrevista; formas de financiamento e fontes de aquisição, características sociodemográficas e presença de doenças crônicas. Foram realizadas análises descritivas e bivariadas, $e$ as principais variáveis foram expressas como frequencias relativas com intervalos de $95 \%$ de confiança (IC95\%). A prevalência do uso de sais de ferros foi 1,6\% (IC95\%: 1,2-2,1), com prevalência maior entre crianças com menos de 1 ano de idade (8,5\%; IC95\%: 6,3-11,5) e residentes da Região Sudeste (2,3\%; IC95\%: 1,5-3,4). A prevalência do uso de vitaminas foi 4,8\% (IC95\%: 4,2-5,6), com prevalência maior entre crianças com menos de 1 ano (24,3\%;IC95\%: 20,3-28,7) e residentes da Região Norte (8,6\%; IC95\%: 6,2-11,7). A aquisição ocorreu por reembolso direto em 41,6\% (IC95\%: 27,9-56,7) dos sais de ferro e em 82,4\% (IC95\%: 76,3-87,2) das vitaminas. Os sais de ferro foram adquiridos predominantemente através das farmácias do SUS (51,5\%; IC95\%: 36,4-66,4), e as vitaminas em farmácias comerciais (80,6\%; IC95\%: 77,4-85, 6). Os resultados sugerem que o uso de sais de ferro na população pediátrica brasileira é por baixo, com uma redução no uso conforme aumenta a idade da criança, além de diferenças regionais e aquisição gratuita, predominantemente do SUS.

Pré-Escolar; Sais de Ferro; Vitaminas; Uso de Medicamentos; Fatores Socioeconômicos

\section{Resumo}

Este trabajo tiene el fin de verificar la prevalencia de uso, adquisición y fuentes de sales de hierro $y$ vitaminas por parte de niños desde 0 a 12 años de edad en Brasil. Se trata de un estudio transversal, basado en población (Encuesta Nacional sobre el Acceso, Uso y Promoción de Uso Racional de Medicinas - PNAUM por sus siglas en portugués), que incluye a 7.528 niños de hasta 12 años de edad. La información se obtuvo a través de cuestionarios respondidos por los tutores de los niños, sobre el uso de sales de hierro $y$ vitaminas 15 dias antes de la entrevista; formas de financiación, y fuentes de adquisición, características sociodemográficas, y presencia de alguna enfermedad crónica. Se realizaron análisis descriptivos y bivariados, además las variables principales se plasmaron mediante frecuencias relativas e intervalos del 95\% de confianza (IC95\%). La prevalencia del uso de sales de hierro fue de un 1,6\% (IC95\%: 1,2-2,1), con una prevalencia más alta entre niños por debajo de un 1 año de edad (8,5\%; IC95\%: 6,3-11,5) y residentes de la Región sudeste (2,3\%; IC95\%: 1,5-3,4). La prevalencia del uso de vitaminas fue de un 4,8\% (IC95\%: 4,2-5,6), con una prevalencia más alta con niños menores de 1 año de edad (24,3\%; IC95\%: 20,3-28,7) y residentes de la Región nordeste (8,6\%; IC95\%: 6,211,7). La adquisición tuvo lugar por reembolso directo en un 41,6\% (IC95\%: 27,9-56,7) de sales de hierro, $y$ por un 82,4\% (IC95\%: 76,3-87,2) de las vitaminas. Las sales de hierro se obtuvieron predominantemente en farmacias del SUS (51,5\%; IC95\%: 36,4-66,4), y las vitaminas en farmacias comerciales (80,6\%; IC95\%: 77,4-85,6). Los resultados sugirieron el consumo de las sales de hierro en la población pediátrica brasileña fue por bajo, con una reducción en su consumo a medida que la edad aumentaba, además de diferencias regionales, y su obtención gratuita, predominantemente del SUS.

Preescolar; Sales de Hierro; Vitaminas; Utilización de Medicamentos; Factores Socioeconómicos

Submitted on 03/Aug/2017

Final version resubmitted on 12/Mar/2018

Approved on 19/Apr/2018 